\title{
Carfilzomib/Dexamethasone Regimen
}

National Cancer Institute

\section{Source}

National Cancer Institute. Carfilzomib/Dexamethasone Regimen. NCI Thesaurus. Code C136265.

A chemotherapy regimen consisting of carfilzomib and dexamethasone that is used for the treatment of plasma cell myeloma. 